\title{
Yaşam Boyu Öğrenmede Öğretmenlerin Kurumları Tara- fından Desteklenmeleri: Ölçek Geliştirme Çalışması
}

\author{
Hande POYRAZ* \\ Mustafa BAYRAKCI ${ }^{* *}$
}

Öz

Öğrencilerin yaşam boyu öğrenen bireyler olarak yetiştirilmesi amaçlanıyorsa, önceliğin onları yetiştirecek öğretmenlerin yaşam boyu öğrenen bireyler olmasına ve bulundukları çevrenin yani okulun öğrencilere öğrenme fırsatları sağlaması gerekmektedir. Bu çalışmada yaşam boyu öğrenme kapsamında öğretmenlerin yaşam boyu öğrenen bireyler olmalarında kurumları tarafından desteklenmeleri ele alınmıştır. Çalışmanın amacı öğretmenlerin kurumları tarafından yaşam boyu öğrenmede desteklenme algılarını belirleyecek bir ölçek geliştirmektir. Bu çalışmayla Sakarya ilinden örneklem olarak seçilen 313 öğretmenle geçerli ve güvenilir "Yaşam Boyu Öğrenmede Öğretmenlerin Kurumları Tarafından Desteklenme Algıları" ölçeği geliştirilmiştir. Araştırmada elde edilen verilere göre; öğretmenlerin okullarının öğrenme topluluğu olması gerektiği ve kendilerinin de bilgi ve iletişim teknolojileri becerileri açısından gelişmelerinin önemli olmasında hemfikirdirler. Okulda çalışan diğer personelin öğretmenlerin öğrenmelerinde bir engel olmadığı ama okulda verilen iş yükünün yaşam boyu öğrenmeye katılımlarında bir engel olduğu bulunmuştur. Analizlerde SPSS 16.0 paket programı kullanılmıştır.

Anahtar Kelimeler: Yaşam boyu öğrenme, okul, öğretmen, okul lideri.

\section{Administrative Support for Teachers' Lifelong Learning: A Study of Scale Development}

Abstract

\begin{abstract}
If the students are to be educated as individuals who are lifelong learners, at first the teachers who educate them should be lifelong learners and the schools should provide learning opportunities to students and teachers. In this study, it is discussed that teachers should be supported by their institutions which mean their schools to become lifelong learners within the scope of becoming lifelong learners. The aim of this study is to prepare a scale that will identify teachers' perception for being supported by their institutions to become lifelong learners. With this study, the valid and reliable "Teachers' Perceptions of Getting Supported by their Institutions in Lifelong Learning" scale was prepared with 313 teachers chosen as sample in Sakarya. According to the data gathered in the research, teachers agree with the idea that schools should be learning communities and it is important that teachers should improve themselves in terms of their skills of information and communication technology. It was figured out that oth-
\end{abstract}

\footnotetext{
* Ankara Üniversitesi Yaşam Boyu Öğrenme ve Yetişkin Eğitimi Programı Doktora öğrencisi
}

** Yrd. Doç. Dr., Sakarya Üniversitesi Eğitim Fakültesi Eğitim Bilimleri Bölümü 
er staff in the school are not barrier for teachers' learning, but their work load assigned at schools is a barrier for their participation in lifelong learning. In the analyses, SPSS 16.0 package programme was applied.

Keywords: Lifelong learning, school, teacher, school leader.

\section{GİRIŞ}

Her alanda ve sürekli değişimin yaşandı̆̆ çağımızda, okulların birer öğrenme topluluğu olması düşüncesiyle okullarda sadece öğrencilerin öğrenme etkinliğine katılmalarının yeterli olmadığı okuldaki tüm personelin bu öğrenme topluluğunun öğrenen birer parçası olması gerektiği açıktır. Bu açıdan bakıldığında yaşam boyu öğrenme bir okuldaki ana oyuncuların; öğrencilerin, ebeveynlerin ve öğretmenlerin okulla ilgili geleneksel fikirlerine meydan okuyan bir yaklaşımdır (Bryce, 2006). Yaşam boyu öğrenmede, öğretmenler hem kendileri yaşam boyu öğrenen bireyler olmalı, hem de öğrencileri yaşam boyu öğrenen bireyler olarak yetiştirmelidir. Etkili profesyonel gelişimin bir sonucu olarak öğretmenlerin değişmesi karmaşık, yönü belli olmayan ve geçmiş deneyimlere, isteğe, yeteneklere, sosyal şartlara ve kurumun desteğine bağlıdır (Day, 1999). Yani bir okulun öğrenme topluluğuna dönüşmesindeki değişimin önderliğini okul müdürlerinin üstlenmesi gerekir. $\mathrm{Bu}$ araştırmayla öğretmenlerin öğrenmelerine devam etmelerinde çalıştıkları kurumlar tarafından desteklenmelerinin incelenmesi ve yaşam boyu öğrenmenin okul liderlerine getirdiği sorumluluklarının tartışılması amaçlanmıştır.

Bir okul sadece öğretmen ve öğrenciden oluşmaz. Okul liderleri ve okulda çalışan diğer personel okuldaki öğrenme toplumunun aktif bir parçası haline gelmelidir. Yetiştikleri programın adı ve süresi ne olursa olsun okulda aldıkları bilgiyle, 25 yıllık meslek hayatlarını tamamlamak alışkanlığı olan öğretmenlerin, öğrencilerine bilginin kutsal bir metin olmad1ğını, sürekli gelişip değiştiğini, yere ve zamana göre anlam kazanana geçici bir birikim oldu- ğunu öğretmeleri kolay değildir (Özden, 2013) Okul liderleri hem öğretmenlerin öğrenmelerine devam etmelerine teşvik edici olmalı hem de herkes için öğrenme fırsatları yaratacak ortamları okuldaki tüm personel ve öğrencilerle de işbirliği içerisinde sağlamalıdır. Okullarda yaşam boyu öğrenmede karşılaşılan temel sorunlar bu büyüklükte bir değişimin hızlıca meydana gelemeyeceğinden kaynaklanmaktadır (Bryce, 2006) ama okullar değişmemek için ne kadar direnirse dirensin, dış faktörler okul sisteminin değişimini gerekli kılacak ve zorlayacaktır (Lee, 2012). Okulların halkın beklentilerini karşılayabilmesi, öğrencilerin çoğunun başarılı olması ve bütün öğrencilerin şimdikinden daha çok öğrendiği yerler olması için liderler yapısal ve kültürel değişimle ilgilenmek zorundadır (Schlechty, 2001). Bu geçişte okul yöneticilerinden beklenen önemli roller şunlardir (Balay, 2004);

- Yüksek düzeyde stratejik planlama kapasitesine sahip olmalı, olay ve ilişkilerin ardındaki büyük resmi görebilmelidir.

- Yüksek düzeyde pazarlama yeteneğine sahip olmalıdir.

- Okullara yeni pazarlama ilgileri yaratmalı ve yeniden yapılaşmış kamu fon kaynağı sağlamalidir.

- Okulların, geniş bir öğrenci kesiminin ve toplumun ihtiyaçlarını karşılayabilecek program ve hizmetler sunabilmesini sağlamalıdır.

- Okulların, hayat boyu eğitimin bir parçası olmasını sağlamalıdır.

- Okulların, okul destek hizmetleri dağıtımının merkezi olmasını sağlamalıdır. 
- Ulusal program çerçevelerinin, okulun özerk yapısını her koşulda azaltmadığının bilincinde olmalıdır.

- Toplumun, okullarının karar alma süreçlerine, geçmişe göre daha aktif bir katılım göstermelerini sağlamalıdır.

- Okulların amaç ve ürünlerine daha çok vurgu yapılacağını bilmeli, eğitim düzeyi oldukça yüksek bir toplumda öğrencilere en iyiyi sunmanın toplumun temel söylemi ve ilgisi haline geleceğini unutmamalıdır.

Araştırmalar bir okuldaki öğrenci başarısı üzerinde bireysel yeteneklerin ötesinde, örgütsel özelliklerin de etkili olduğunu göstermektedir (Özden, 2013). Bu da yaşam boyu öğrenme için okullarda öğrenme kültürünün oluşturulmasının önemli olduğunu gösterir. Öğrenme kültürü uygulamayı ve uygulamanın öğrenme çıktılarına etkilerini anlamamıza yardımcı olur çünkü (Ecclestone, Davies, Derrick, \& Gawn, 2010):

Öğrenmeyi etkileyen karşılıklı ilişkilerin ne kadar karmaşık olduğunu gösterir.

Herhangi bir konumda dışsal ve içsel faktörlerin öğrenmeyi nasıl etkilediğini gösterir.

Etkili öğrenmede engelleri ve tabi ki de etkili öğrenmeyi teşvik eden sinerjiyi belirlemeyi mümkün kılar.

Belli bir rehber veya öğretme takımının olanakları dâhilinde ya da ötesinde öğrenmede etkililiğin olduğuna açılık getirir.

Olası istenmeyen öğrenmelerde farkındalık yaratır ve öğrenmenin etkililiği de dâhil, öğrenmenin değeri hakkında dikkate alınan yargilara olanak sağlar.

Öğrenme toplumu olan okullarda (Hargreaves, 2004);

Öğrenme süreklidir, stratejik bir süreçtir, işle içiçe ve işe paraleldir;
Öğrenme okulun etkileşim içinde olduğu bireylerle, takımlarla ve diğer kurumlarla gerçekleşir.

Öğrenme kendini gözleme, değerlendirme ve geliştirmeden doğan işbirliğinin çıktısıdır.

Bir okulda yaşam boyu öğrenen bireylerin yetiştirilmesi amaçlanıyorsa okulların da yaşam boyu öğrenmeye yönelmelidirler, yaşam boyu öğrenmeye yönelen okullar (Bryce, 2006);

Bilgi okuryazarlığına önem verir;

Bazı/belli değerleri, yetenekleri ve tutumları vurgular;

"Temel Becerilerin" ötesindeki bazı/belli becerileri vurgular;

Öğrenmeyi öğrenmede, öz-kavram ve özdüzenlemenin önemini kabul eder;

Yaşam boyu öğrenmede öğretmenlerin rol model ve destekçi olduklarının önemini kabul eder.

Alanında çok iyi yetiştiği ve kendini mesleğine adadığı halde "örgütsel kapasite"nin yetersizliğinden dolayı verimli olamayan öğretmenlerin sayısı hiç de az değildir. Eğer okul yöneticileri okullarındaki öğretmenlerin ortak notalarda odaklaşmasını sağlayamaz, onlara birbirlerinden öğrenme firsatı veremez ise, en yetenekli öğretmenler bile başarılı olamayacaktır (Özden, 2013). Öğretmenler ve bulundukları öğretme, profesyonel öğrenme ve gelişim durumları hakkında on gerçek (Day, 1999);

Öğretmenler okulların en değerli varlığıdır. Bilginin, becerilerin ve değerlerin aktarılmasında aradaki bağı kurarlar. Öğretmenler eğer mesleğe iyi hazırlanmış ve kariyerleri boyunca mesleklerine katkı da bulunabilecek ve mesleklerini geliştirebileceklerse eğitimsel hedefleri yerine getirebilirler. Refahları ve profesyonel gelişimleri için bu yüzden desteklenmeleri 
öğretme, öğrenme ve başarıyı arttırma çabalarının ayrılmaz ve önemli parçasıdır.

Tüm öğretmenlerin en önemli görevi öğrencilerine yaşam boyu öğrenmeyi aşılamalarıdır. $\mathrm{Bu}$ yüzden, yaşam boyu öğrenmeye isteklerini ve katılımlarını göstermelidirler.

Değişime ayak uydurmak ve başarılı öğretim için kendi bilgilerini, becerilerini ve vizyonlarını gözden geçirmek ve yenilemek için devam eden kariyer süresince profesyonel gelişme öğretmenler için önemlidir.

Öğretmenler kariyerleri boyunca doğal olarak öğrenirler. Her ne kadar sadece tecrübelerden öğrenme gelişimi tamamen sınırlandıracaktır.

Öğretmenlerin düşünceleri ve hareketleri yaşam tecrübelerinin, şimdiki gelişim durumlarının, sınıf ve okul ortamlarının ve çalıştıkları sosyal ve politik durumların etkileşiminin sonucudur.

Sınıflar farklı öğrenmeye karşı faklı eğilimlere ve güdülere sahip, farklı becerileri olan ve farklı yerlerden gelen öğrencilerden oluşur. Bu yüzden öğretme karışık bir süreçtir. Kurumdaki karmaşa azaltılsa da başarılı öğretim hem içsel ve kişisel arası beceriler hem de kişisel ve profesyonel katılım gerektirir. Akıl ve kalbin bir sentezidir.

Müfredatın anlaşılış biçimi öğretmenlerin kişisel ve profesyonel kimliklerinin yapısıyla ilişkilidir. Kavram ve pedagojik bilgi bu yüzden öğretmenin kişisel ve profesyonel ihtiyaçlarından ve manevi amaçlarından ayrı tutulamaz. Yani profesyonel gelişme bunlara da önem vermelidir.

Öğretmenler geliştirilemezler (pasif bir şekilde). Gelişirler (aktif olarak). Kendi öğrenmelerinin yönüne ve sürecine karar vermede merkezde olmaları bu yüzden çok önemlidir.
Başarılı okul gelişimi başarılı öğretmen gelişimine bağlıdır.

Kariyer süresince planlama ve destekleme öğretmenlerin, okulun ve hükümetin ortak sorumluluğundadır.

\section{YÖNTEM}

Çalışmanın amacı öğretmenlerin kurumları tarafından yaşam boyu öğrenmede desteklenmeleri algılarını belirleyecek bir ölçek geliştirmektir. Yaşam boyu öğrenmede öğretmenlerin kurumları tarafından desteklenme algıları incelenmesine yönelik olan hazırlanan ölçme aracının geliştirilmesinde; madde oluşturma, uzman görüşüne başvurularak içerik geçerliliği, geçerlik ve güvenirlik hesaplama aşaması izlenmiştir (Karasar, 2002; Balcı, 2005).

\section{1 Örneklem}

$\mathrm{Bu}$ araştırma yaşam boyu öğrenmede öğretmenlerin kurumları tarafından desteklenme algiları incelenmesine yönelik bir ölçek geliştirme çalışmasıdır ve evrenini 2012-2013 eğitim öğretim yılında Sakarya ilinde görev yapan 8.747 öğretmendir. Kabul edilebilir \%5 hatayla 8.747 kişilik evren için \%90 güven seviyesinde önerilen örneklem büyüklügü 263'tür ama örneklemin evreni daha iyi temsil etmesi için örneklem sayısının fazla tutulması gerekmektedir (Büyüköztürk, 2004). Bu çalışmada örneklemi bu evrenden kolay örneklem olarak seçilen 313 öğretmen oluşmaktadır. Araştırmaya katılan öğretmenlerin demografik özellikleri araştırmacı tarafından hazırlanmış ve örneklemin sosyo-demografik bilgilerini elde etmek için kullanılmış olan kişisel bilgiler formuyla elde edilmiş ve ilgili bilgiler Tablo 1'de verilmiştir.

Tablo 1. Araştırma Örnekleminin Sosyo-Demografik Özellikleri 


\begin{tabular}{|c|c|c|c|c|c|}
\hline Değişken & $\mathrm{n}$ & $\%$ & Değişken & $\mathrm{n}$ & $\%$ \\
\hline Cinsiyet & & & Branş & & \\
\hline Erkek & 110 & 35.1 & Sınıf öğretmeni & 65 & 20.8 \\
\hline Kadın & 203 & 64.9 & Branş öğretmeni & 248 & 79.2 \\
\hline Meslekteki Yıl & & & Medeni Hal & & \\
\hline $1-10$ yıl & 176 & 56.2 & Evli & 184 & 58.8 \\
\hline $11-20$ yil & 112 & 35.8 & & & \\
\hline 20 yıl ve üzeri & 25 & 8.0 & Bekar & 129 & 41.2 \\
\hline Eğitim Durumu & & & Yaş & & \\
\hline Ön-lisans & 35 & 11.2 & $20-30$ & 144 & 46.0 \\
\hline Eğitim Fakültesi & 229 & 73.2 & $31-40$ & 133 & 42.5 \\
\hline Lisansüstü & 49 & 15.7 & 41 ve üzeri & 36 & 11.5 \\
\hline
\end{tabular}

\subsection{Verilerin Analizi}

Verilerin analizleri SPSS 16.0 (Statistical Package for Social Science) istatistik paket programıyla yapılmıştır. Geçerlik çalışması için, kapsam geçerliği ve faktör analizi ile yapı geçerliliği incelenmiştir. Scree test ve AFA'da asal eksenlere göre döndürülmüş temel bileşenler analizi sonuçlarına bakılarak karar verilmiştir. Güvenirliği için iç tutarlık katsayıları (Cronbach Alpha) hesaplanmıştır. Ölçeğe verilen cevapların yorumlanmasinda ortalama ve standart sapma değerlerine bakılmıştır.

\section{BULGULAR VE YORUM}

3.1 Yaşam Boyu Öğrenmede Öğretmenlerin Kurumları Tarafından Desteklenme Algıları Ölçeği'nin Geçerliliğine İlişkin Bulgular

Geçerlik, testin bireyin ölçülmek istenen özelliğini ne derece doğru ölçtüğüyle ilgili bir kavramdır. Geçerlik teknikleri için değişik sınıflandırmalardan bahsedilebilir. Bu sınıflandırma içinde daha çok tercih edileni şudur: a) kapsam geçerliği, b) ölçüt-bağımlı geçerlik ve c)yapı geçerliği (Büyüköztürk, 2004).

Kapsam geçerliği, bir bütün olarak ölçeğin ve ölçekteki her bir maddenin amaca ne derece hizmet ettiğidir (Tekin, 1977). Kapsam geçerliği için öncelikle ölçüm konusu kavramsal olarak tanımlanmış bu doğrultuda ölçekteki her maddenin ve bunların dağılımının ölçüm konusunu örnekleyip örneklemeyeceği araştırılmıştır. Yaşam Boyu Öğrenmede Öğretmenlerin Kurumları Tarafından Desteklenme Algıları Ölçeğinin maddeleri ilgili literatür tarandıktan sonra öğretim üyelerinin de görüşleri doğrultusunda 12 madde olarak hazırlanmıştır. Ölçekteki maddeler "kesinlikle katıllyorum", "katıl1yorum", "fikrim yok", “katılmiyorum”, “kesinlikle katılmıyorum" şeklinde belirtilen 5'li dereceleme ölçeğinde düzenlenmiştir. Bu ölçekle öğretmenlerin kurumlarındaki hakim olan kültür, yöneticilerin yaşam boyu öğrenmeye katılımlarına karşı olan destekleri, kurumdaki iş yükü ve diğer çalışanlarla aralarındaki ilişki hakkındaki görüşlerini incelenmesi amaçlanmiştır.

Yapı geçerliği testin ölçülmek istenen davranış bağlamında soyut bir kavramı (faktörü) doğru bir şekilde ölçebilme derecesini gösterir. Yapı geçerliğini incelemek amacıyla sıklıkla kullanılan açımlayıcı faktör analizi kullanılabilir. Faktör analizi maddelerin faktör yük değerlerini 
kullanarak kavramların işlevsel tanımlarını elde etme süreci olarak da tanımlanmaktadır (Büyüköztürk, 2004). Her özdeğerin bir grafikte gösterildiği ve grafikteki monoton dağılımın bozulduğu sivrilme noktasına göre faktör sayısının belirlendiği scree teste (Akbulut, 2010) göre Özdeğer-Faktör grafiğinde, grafik eğrisinin hızlı bir düşüş gösterdiği nokta ilk faktörden itibaren başlamaktadır. Bundan hareketle ölçekteki faktör sayısının 1 ile sınırlandırılabi- leceği kararlaştırılmıştır. Bu araştırmada tek boyutlu bir ölçek geliştirilmesi amaçlandığı için $\mathrm{AFA}^{\prime}$ da asal eksenlere göre döndürülmüş temel bileşenler analizi kullanılmıştır. Bu işlem sonucunda toplam varyansin \% 52,89'unu açıklayan tek faktörlü bir yapı elde etmiştir. Tek faktörlü ölçeklerde açıklanan varyansın \%30 ve daha fazla olması yeterli görülebilir (Büyüköztürk, 2004).

\section{Scree Plot}

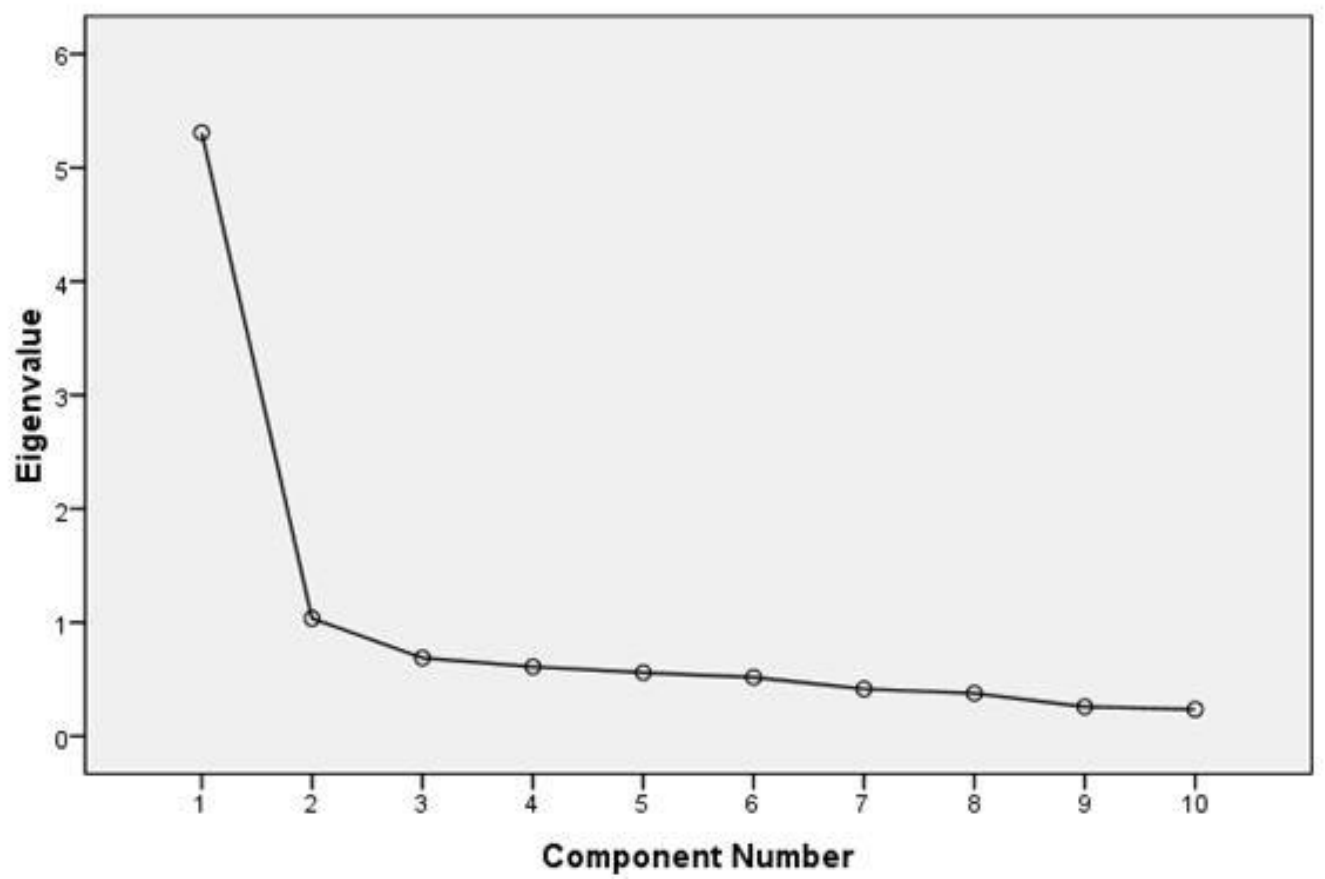

Şekil 1. Özdeğer- Faktör Grafiği

Yaşam boyu öğrenmede öğretmenlerin kurumları tarafindan desteklenme algıları ölçeğinin madde analizi için madde-toplam korelâsyonları hesaplanmıştır. Yapılan analiz sonucunda ölçeğin düzeltilmiş madde-toplam korelâsyonlarının .75 ile .60 arasında değiştiği görülmüştür. Bulgular Tablo 2'de gösterilmiştir. Yaşam boyu öğrenmede öğret- menlerin kurumları tarafından desteklenme algıları ölçeğinin geçerlik çalışması olarak yapı geçerliği kapsamında açımlayıcı faktör analizi (AFA) uygulanmıştır. Faktör yükü ,30'un altında olan iki madde ölçekten çıkarılmıştır. Her bir faktöre ait maddelerin faktör yükleri Tablo 2'de verilmiştir.

Tablo 2. Yaşam Boyu Öğrenmede Öğretmenlerin Kurumları Tarafından Desteklenme Algıları

Madde toplam Faktör

korelasyonları yükü 


\begin{tabular}{lll}
\hline d1 &, 66 &, 744 \\
\hline d2 &, 65 &, 731 \\
\hline d3 &, 75 &, 817 \\
\hline d4 &, 68 &, 758 \\
\hline d5 &, 60 &, 684 \\
\hline d6 &, 66 &, 739 \\
\hline d7 &, 62 &, 702 \\
\hline d8 &, 62 &, 699 \\
\hline d9 &, 62 &, 697 \\
\hline d10 &, 61 &, 693 \\
\hline
\end{tabular}

3.2 Yaşam Boyu Öğrenmede Öğretmenlerin Kurumları Tarafından Desteklenme Algıları Ölçeği'nin Güvenilirliğine İlişkin Bulgular

Cronbach alpha katsayısı yöntemi, maddeler doğru-yanlış olacak şekilde puanlanmadığında, 1-3, 1-4, 1-5 gibi puanlandığında, kullanılması uygun olan bir iç tutarlılık tahmin yöntemidir (Öncü,1994). Cronbach alfa katsayısı, ölçekte yer alan $\mathrm{k}$ maddenin varyansları toplamının genel varyansa oranlanması ile bulunan bir ağırlıklı standart değişim ortalamasıdır (Özdamar, 2012). ÖKTDA ölçeğinin bütünü için hesaplanan iç tutarlılık katsayısı .90 olarak bulunmuştur. Buna göre ölçeğin güvenirliğinin oldukça yüksek olduğu söylenebilir. Cronbach Alpha güvenirlik katsayısının bire yakınlığı, ölçekteki her bir maddenin aynı tutumu ölçtüğü anlamına gelir. Bu katsayı, iç tutarlık ve homojenliğin bir ölçüsüdür. Buna göre Yaşam Boyu Öğrenmede Öğretmenlerin Kurumları Tarafından Desteklenme Algıları Ölçeği, Cronbach Alpha güvenirlik katsayısı tarafından belirlenen yüksek güvenirlik derecesi göstermiştir. Bu da ölçeğin tutarlı ve güvenilir bir ölçek olduğunu göstermektedir.

Aşağıdaki tabloda öğretmenlerin yaşam boyu öğrenmede öğretmenlerin kurumları tarafından desteklenme algıları ölçeğine verdikleri cevapların ortalamaları ve standart sapmaları yer almaktadır (Tablo 3). Öğretmenlerin Yaşam Boyu Öğrenmede Öğretmenlerin Kurumları Tarafından Desteklenme Algıları düzeyleri ile ilgili genel aritmetik ortalama 37,99, standart sapması ise $7,25^{\prime}$ tir.

Tablo 3. Yaşam Boyu Öğrenmede Öğretmenlerin Kurumları Tarafından Desteklenme Algıları

\begin{tabular}{|c|c|c|}
\hline $\begin{array}{l}\text { Yaşam Boyu Öğrenmede Öğretmenlerin Kurumları Tarafından Desteklenme Alg1- } \\
\text { ları }\end{array}$ & $\bar{x}$ & Ss \\
\hline 1.Çalıştı̆̆ım okuldaki politikalar öğrenmeye devam etmeme katkı sağlıyor. & 3,64 & 1,05 \\
\hline 2. Okulumuz için bilgi ve iletişim teknolojileri becerilerimizin gelişmesi önemlidir. & 4,01 & ,99 \\
\hline 3. Okulda hâkim olan kültür yaşam boyu öğrenmeye katılıma teşvik ediyor. & 3,67 & 1,02 \\
\hline 4. Okulun stratejik planlamasında yaşam boyu öğrenmeye de yer verilmiştir. & 3,67 & 99 \\
\hline 5.Okulumuzun öğrenme toplumu olması bizim için önemlidir. & 4,06 & 83 \\
\hline $\begin{array}{l}\text { 6. Okulumuz diğer kuruluşlarla öğrencilere öğrenme imkânları sağlamak için işbirliği } \\
\text { içerisinde. }\end{array}$ & 3,71 & 1,03 \\
\hline 7.Okulda bilgi ve iletişim teknolojilerine ulaşmamıza imkân sağlanıyor. & 3,81 & 1,04 \\
\hline 8. Okulda verilen iş yükü yaşam boyu öğrenmeye katılımıma bir engel değildir. & 3,56 & 1,12 \\
\hline 9. Okuldaki görevlerim öğrenmeme bir engel değil. & 3,86 & ,99 \\
\hline 10. Okulda çalışan diğer personel öğrenmeye katılımımda bir engel oluşturmuyor. & 4,00 & 86 \\
\hline Toplam & 37,99 & 7,25 \\
\hline
\end{tabular}

Tablo 3'e göre öğretmenler, öğretmenlerin okulları tarafından desteklenme algılarında en 
çok katılımı "5.Okulumuzun öğrenme toplumu olması bizim için önemlidir. $(=4,06)$ ”, “2. Okulumuz için bilgi ve iletişim teknolojileri becerilerimizin gelişmesi önemlidir. $(=4,01)^{\prime \prime}$ ve "10.Okulda çalışan diğer personel öğrenmeye katılımımda bir engel oluşturmuyor. $(=4)^{\prime \prime}$ maddelerinde göstermişlerdir. En az katılım ise "8. Okulda verilen iş yükü yaşam boyu öğrenmeye katılımıma bir engel değildir. $(=3,56)$ ", "1.Çalıştığım okuldaki politikalar öğrenmeye devam etmeme katkı sağlıyor. $(=3,64)$, "3.Okulda hâkim olan kültür yaşam boyu öğrenmeye katılıma teşvik ediyor. $(=3,67)$ " ve "4.Okulun stratejik planlamasında yaşam boyu öğrenmeye de yer verilmiştir. $(=3,67)$ "' maddelerinde görülmüştür.

\section{SONUÇ VE ÖNERİLER}

Okulun yönetiminde kurallar, roller, birimler arası ilişkiler ve sorumlulukların daha az hiyerarşik ve daha esnek şekilde düzenlenmesi gerekmektedir (Özden, 2013). Okul, değişmenin merkezi olduğuna göre odak, tutarlılık ve uyumun okulda olması gerektiği anlaşılmaktadır. Pek tabii ki başarılı bir okul geliştirmede okul yöneticisi, çok merkezi bir konumdadır (Balc1, 2013).

Yaşam boyu öğrenmeye yönelmiş bir okulda (Bryce, 2006); öğrencilere kendi öğrenme amaçlarını belirlemede ve değerlendirme yardım edilir ve öğrencilerle öğrenme sahiplenilir, sert düşey yapının yerine okullarda öğrenme merkezleri vardır, öğrencilerin düşünmesi ve göstermesi için zaman ve destek sağlanır ve bu danışman rolünü üstlenen bir kişi tarafından yapılır, öğretmenler kendileri yaşam boyu öğrenen birey modelidir, yarıştırıcı değerlendirme yerine biçimlendirici değerlendirmeye önem verilir, öğrenmenin eğlenceli olduğu bir çevre vardır. Ayrıca okullarda yaşam boyu öğrenme becerileri aşağıdaki dört alana önem verilerek daha hızlı geliştirilebilir (Demirel, 2009):
1. Farklı eğitim stratejileri kullanmak önemlidir. Öğrenciler çeşitli yollardan öğrenebileceklerinden eğitim süreci de bununla uyumlu olmalıdır. Farklı stratejiler etkili öğrenme için birleştirilmeli ve aktif öğrenme süreçlerine daha çok önem verilmelidir.

2. Eğitimin planlanması, uygulanması ve değerlendirilmesi etkili öğrenme ve öğretme için önemlidir. Okuldaki sınıf içi değerlendirme sistemi eğitim sistemiyle de uyum içinde olmalıdır. Aksi takdirde, süreçler arasında kesinti olabilir ve öğrenmeye erişim aksayabilir.

3. Geri dönütler öğrencilerin kendi hatalarını gözden geçirmelerini, çalışmalarını ve tekrar düşünmelerini sağlayacak şekilde anlamlı ve motive edici olmalıdır. Öğrencilerin sahip olması beklenen bilgiyi pekiştirmekte bu sürece dâhildir. Mantıken, tüm ev ödevleri için bu uygulanabilir olmayabilir; ama seçici davranıldığında etkili olabilir. $\mathrm{Bu}$ öğrenciye ve öğrenme sürecine gösterilen saygının ve değerin göstergesidir.

4. Sınıf dışında da uygulanabilirlik öğrencilerin kendi beceri ve bilgilerini sınamaların sağlar. Öğrenciler öğrendiklerinin uygulanabilirliğini fark ettiklerinde, kendi öğrenmelerine yatırıma daha meyilli olacaklardır. Uygulanabilirlik firsatları faklı ortamlarda olabilir. Bunların arasında sosyal hizmetler, danışmanlık, sergileme, seminer veya bir müze ya da kütüphane sergisi yer alır.

Araştırmada elde edilen verilere göre; öğretmenlerin okullarının öğrenme topluluğu olması gerektiği ve kendilerinin de bilgi ve iletişim teknolojileri becerileri açısından gelişmelerinin önemli olmasında hemfikirdirler. Okulda çalışan diğer personelin öğretmenlerin öğrenmelerinde bir engel olmadığı ama okulda verilen iş yükünün yaşam boyu öğrenmeye katılımlarında bir engel olduğu bulunmuştur. Öğretmenle- 
rin en az katılım gösterdiği maddeler "1.Çalıştığım okuldaki politikalar öğrenmeye devam etmeme katkı sağlıyor.","3.Okulda hâkim olan kültür yaşam boyu öğrenmeye katılıma teşvik ediyor. " ve "4.Okulun stratejik planlamasında yaşam boyu öğrenmeye de yer verilmiştir." - doğrultusunda okul liderlerine şu önerilerde bulunulabilir; okulların ilerlemesinde anahtar nokta, okulları kurum olmaktan toplum olmaya dönüştürmededir.

Day, (1999) öğretmenlerin öğrenmelerinin okul kültüründen, okul yöneticileri ve akran desteğinden, etkilendiğini söylemiştir. Okuldaki yöneticiler eğer hem kendileri hem de çalışanları için düzenli bir öğrenmeyi amaçlıyorsa yükseköğretimden rehberler ve bölümleriyle etkili bir şekilde çalışmalıdırlar. Her türlü eğitim kurumunun, etkinliğinin ve sürecinin örgün ve yaygın, sabit ve yaşam boyu- doğasını, hedeflerini ve amaçlarını belirlemek ve özellikle bu etkinliklerin yaşam boyu öğrenme programlarına katkıları hakkında açık olacaksak mükemmelliğini, etkililiğini ve kalitesini arttırmak için çabaladığımızda aşağıdaki gibi pragmatik metotların uygulanmasını önemlidir (Aspin \& Chapman, 2007);

- Yaşam boyu öğrenme alanıyla ilgilenen araştırmacılar, politikacılar ve uygulayıc1ların çalıştıkları soruları, sorunları, kategorileri ve kriterleri anlamaya çalışmak

- Uygulamadaki araştırmacılar, politikacılar ve uygulayıcılarla teoriler belirlemek

- $\quad \mathrm{Bu}$ tarz teorilerin, politikaların ve uygulamaların kavramında ve uygulanmasındaki başarı ve başarısızlığın nedenlerini anlamaya çalışmak.

Öğretmenlerin işleri tek başlarına olmadıkları, planlamada işbirlikçi oldukları, öğretimlerinin çıtı odaklı olduğu ve öğrenciler ve ebeveynlerle açıkça anlaşmalı olduğu bir hal almaktadır (Day, 1999). Öğrenme ve öğretmeye ilişkin yeni değerler öğrenmenin öğrenci merkezli olarak yeniden düzenlenmesini öngörmektedir. Vurgu öğrencidedir, bilginin aktarılmasında değil. Bilgi edinme değil, bilgiyi kullanma ve ondan yeni bilgi üretme önemlidir. Bunun için öğretmenin "bilgi aktaran konumundan, öğretirken öğrenen bir konuma" geçmesi gerekmektedir (Özden, 2013). Öğretmenlerin bu beklentiyi karşılayabilmesi için pek çok merkezden yardım alması gerekli olabilir. Bu merkezler aşağıda kısaca tanıtılmaktadır (Balcı, 2013):

- Bilgisayar destekli merkez: bilgisayar teknolojisinin program ve öğretime uygulayan uzmanlardan kuruludur. Uzmanlar merkezde bilgisayar simülasyonları geliştirirler. Başkalarının geliştirdiği programlı öğretim materyallerini otomatikleştirirler.

- Kendi kendine öğretim merkezi: programlanmış materyal ve kendi-kendine öğretim paketleri sağlar. Bunları konu uzmanları ile danışarak geliştirir.

- Araştırma merkezi: çok gelişmiş bir kitaplık gibidir. Filmler, teyp kayıtları bulunur; öğrenciler merkezden kendi kişisel araştırmalarını yaparken yararlanırlar.

- Araç geliştirme merkezi: profesyonel yazarlar, sanatçılar, gör-işit uzmanlarından oluşur. Merkezde öğrencilerin öğrenme ihtiyaçlarına uyacak görsel ve yazılı materyaller üretilir.

- İnsan ilişkileri merkezi: bu merkez öğrenci ve personele danışmanlık ve insan ilişkilerinde yetişme sağlar.

- Danışmanlık ve değerlendirme merkezi: merkez personeli bilgisayar destekli merkez ve insan ilişkileri merkezi personeliyle birlikte çalışır ve bireysel öğrenci gelişimini teşhis etmek ve uygun reçete vermekle yükümlüdür; bu merkezde testler ve diğer değerleme araçları geliştirilir. 
Yaşam boyu öğrenmeyle gelen değişimde okul liderleri (Day,1999); açıkça tanımlanmış ve hedeflenmiş profesyonel ve kariyer gelişim ihtiyaçlarını belirlemeli, işbirlikçi yönetim kültürünü oluşturmalı ki okul vizyon ve hedeflerine katılım artsın, tüm okul arasında etkileşimi geliştirmeli, diğer okullarla işbirliğinde olmalıdır ayrıca öğrenme fırsatlarını ortaya çıkartmalı, okulu kaynaklandırmalı ve çalışanların özgüvenlerini geliştirmeli ve öğretmenlere yatırım yapmalıdır. Okul müdürleri öğretmenlerin yaşam boyu öğrenmeye devam etmeleri

\section{Kaynakça}

Akbulut, Y. (2010). Sosyal bilimlerde SPSS uygulamaları. İstanbul: İdeal Kültür Yayıncllık.

Aspin, D. N., \& Chapman, J. D. (2007). Lifelong Learning: Concepts and Conceptions. D. N. Aspin içinde, Philosophical Perspectives on Lifelong Learning. Springer.

Balay, R. (2004). Küreselleşme, bilgi toplumu ve eğitim. Ankara Üniversitesi Eğitim Bilimleri Fakültesi Dergisi, $37(2), 61-82$.

Balc1, A. (2005). Sosyal bilimlerde araştırma yöntem, teknik ve ilkeleri. Ankara: Pegem-A Yayınevi.

Balcı, A. (2013). Etkili Okul ve Okul Geliştirme. Ankara: Pegem Akademi.

Bryce, J. (2006). Schools and Lifelong Learners. J. Chapman, P. Cartwright, \& E. J. McGilp içinde, Lifelong Learning, Participation and Equity (s. 243-263). Dordrecht: Springer.

Büyüköztürk, Ş. (2004). Veri Analizi El Kitabı. Ankara: Pegem A Yayıncılık.

Day, C. (1999). Developing Teachers: The Challenges of Lifelong Learning. London: Falmer Press.

Demirel, M. (2009). Implications of Lifelong Learning on Educational Institutions. Cypriot Journal of Educational Sciences (CJES)(4), 199-211.

Ecclestone, K., Davies, J., Derrick, J., \& Gawn, J. (2010). Transforming Formative Assessment in Lifelong Learning. Berkshire - England: Open University Press.

Hargreaves, D. H. (2004). Learning for Life: The Foundations for Lifelong Learning. Bristol: The Policy Press.

Karasar, N. (2002). Bilimsel Araştırma Yönetimi. Ankara: Nobel Yayınevi.

Lee, W. O. (2012). Learning for the future: the emergence of lifelong learning and the internationalisation of education as the fourth way? Educational Research for Policy and Practice, 1(11), 53-64.

Merriänboer, J. J., \& Stoyanov, S. (2008). Learners in a Changing Learning Landscape: Reflections from an Instructional Design Perspective. J. Visser, \& M. Visser-Valfrey (Dü) içinde, Learners in a Changing Learning Landscape: Reflections from a Dialogue on New Roles and Expectations (s. 69-90). Springer Netherlands.

Öncü, H. (1994). Eğitimde Ölçme ve Değerlendirme. Ankara: Matser Basım.

Özdamar, K. (2002). Paket Programlarla İstatistiksel Veri Analizi-1 (4. b.). Eskişehir: Kaan Kitabevi.

Özden, Y. (2013). Eğitimde Yeni Değerler: Eğitimde Dönüşüm. Ankara: Pegem Akademi.

Schlechty, C. P. (2001). Okulu Yeniden Kurmak. (Y. Özden, Çev.) Ankara: Nobel Yayını.

Tekin, H. (1977). Eğitimde Ölçme ve Değerlendirme. Ankara: Mars Matbaası. 


\section{Extended Summary}

For schools, the term 'Lifelong Learning' represents an immense change in orientation. In this study, it is discussed that teachers should be supported by their institutions which mean their schools to become lifelong learners within the scope of becoming lifelong learners. Because for many teachers, the change from a traditional role of imparting knowledge to facilitating lifelong learning poses a significant challenge. If schools are to be part of the lifelong learning community they need to be concerned with the lifelong development of all their members. The main challenges to lifelong learning in schools stem from the fact that change of this magnitude cannot occur quickly. The key players: students, parents and teachers will take time to evaluate the worth of this new approach that challenges their traditional views of schooling (Bryce, 2006; Day, 1999).

The aim of this study is to prepare a valid and reliable scale that will identify teachers' perception for being supported by their institutions to become lifelong learners. The population of the research is 8.747 primary teachers in 2012-2013 term in Sakarya and the sample of research is 313 primary teacher from this population. "Teachers' Perceptions of Getting Supported by their Institutions in Lifelong Learning" scale was developed after literature review, expert opinions, administering surveys, and running factor analysis and reliability tests. Validity and reliability analysis are done by SPSS 16.0 package programme. The results of the Explanatory Factor Analysis on a 12 items five-point Likert type scale and sree-test showed that the instrument has one dimension and it explains $52,89 \%$ of the total variance. Also scale has Cronbach's alpha reliability coefficient of .90 which indicates that scale is highly reliable.

According to the results of "Teachers' Perceptions of Getting Supported by their Institutions in Lifelong Learning", mean of the scale is 37,99 and standart deviation is 7,25 . Teachers are more agree with the " 5 . It is important for us that schools should be learning communities" $(=4,06)$ ", “2. It is important that teachers should improve themselves in terms of their skills of information and communication technology. $(=4,01)$ " and "10. Other staff in the school are not barrier for my learning. $(=4)$ " dimensions. While teachers are less agree with "8. My work load assigned at schools is a barrier for participating learning. $(=3,56)$ ", "1. Policies in my school supports me to keep on learning." $(=3,64)$, "3. School culture encourages me to engage in lifelong learning. $(=3,67)$ " ve " 4 . Lifelong learning is among our school's strategic plans. $(=3,67)$ " dimensions.

To sum up, in this study “Teachers' Perceptions of Getting Supported by their Institutions in Lifelong Learning" scale which is both reliable and valid is developed so it can be used in different sample group and different educational institutions. Also it is clear that teachers agree with the idea that schools should be learning communities and it is important that teachers should improve themselves in terms of their skills of information and communication technology. It was figured out that other staff in the school are not barrier for teachers' learning, but their work load assigned at schools is a barrier for their participation in lifelong learning. 